Центр воєнно-стратегічних досліджень Національного університету оборони України імені Івана Черняховського, Київ

\title{
Удосконалена методика оцінювання рівня досягнення стратегічних цілей розвитку Збройних Сил за результатами проведеної оборонної реформи
}

Резюме. У статті запропоновано використання удосконаленої методики оцінювання рівня досягнення стратегічних цілей розвитку Збройних Сил за результатами проведеної оборонної реформи під час оборонного огляду.

Ключові слова: методика; розвиток Збройних Сил; результати оборонної реформи; стратегічні цілі; оборонний огляд.

Постановка проблеми. Одним із завдань науково-методичного забезпечення оборонного огляду $\epsilon$ розроблення та використання методів i методик для оцінювання рівня досягнення стратегічних цілей розвитку Збройних Сил за результатами проведеної оборонної реформи, які забезпечать прийняття обгрунтованих рішень і розроблення відповідних рекомендацій [1-4].

Аналіз останніх досліджень i публікацій. Проблемі оцінювання досягнення стратегічних (оперативних) цілей для прийняття обгрунтованих управлінських рішень присвячено публікації [5-14].

Так, у статті [5] запропоновано методику оцінювання досягнення стратегічних (оперативних) цілей Плану дій щодо впровадження оборонної реформи у 2016 -

$$
Z_{i j k}=\sum_{n=1}^{N} K_{i j k(n)} \cdot R_{i j k(n)} \text {, при фіксованих } i=\overline{1, I}, j=\overline{1, J}, k=\overline{1, K} \text {, }
$$

де $Z_{i j k}$ - показник виконання $k$-го

завдання $j$-ї оперативної цілі $i$-ї стратегічної цілі;

$K_{i j k(n)}$ - коефіцієнт важливості $n$-го заходу $k$-го завдання $j$-ї оперативної цілі $i$-ї стратегічної цілі, до того ж $\sum_{n=1}^{N} K_{i j k(n)}=1,0$;

$R_{i j k(n)}$ - відсоток виконання $n$-го заходу $k$-го завдання $j$-ї оперативної цілі $i$-ї стратегічної цілі.

Аналогічно залежності (1) запропоновано оцінювати показники досягнення стратегічних (оперативних) цілей Плану дій щодо впровадження оборонної реформи у 2016 2020 роках.

Однак, запропонована методика не передбачає використання критерію досягнення
2020 роках [2], яка, на думку авторів, дає змогу забезпечити керівництво МО України та Генерального штабу ЗС України оперативною та об'єктивною інформацією про стан виконання заходів, визначених дорожньою картою оборонної реформи.

В основу цієї методики покладено використання методу “дерева цілей” та суб'єктивного оцінювання, а саме визначення експертною групою коефіцієнтів важливості для кожного показника виконання заходів (завдань, оперативних і стратегічних цілей), що дає змогу отримувати узагальнену інформацію для Комітету реформ МО України та 3С України.

Автори запропонованої методики для оцінювання показників виконання завдань використали адитивну згортку типу [5]:

стратегічних цілей і мети оборонної реформи, що не дає змогу оцінити ефективність проведення оборонної реформи, або ризики досягнення, а також потребує значних затрат часу на визначення експертами коефіцієнтів важливості, які істотно не впливають на результат.

У працях [6-14] наведено інші методи, методики та підходи, які можуть бути використані для вдосконалення існуючої методики оцінювання досягнення стратегічних (оперативних) цілей Плану дій щодо впровадження оборонної реформи у 2016 - 2020 роках.

Метою статті $\epsilon$ удосконалення методики оцінювання рівня досягнення стратегічних цілей розвитку Збройних Сил за результатами проведеної оборонної реформи, для підвищення об’єктивності оцінювання під 
час оборонного огляду та визначення ризиків досягнення.

Викладення основного матеріалу. Розроблення пакету стратегічних документів для розвитку спроможностей ЗС України та інших складових сил оборони на довгострокову перспективу потребує удосконалення відповідного науково-методичного апарату щодо визначення стратегічних цілей та пріоритетних напрямів розвитку спроможностей 3С України.

За допомогою декомпозиції проведено розділення мети оборонної реформи, визначеної Стратегічним оборонним бюлетенем України [1] за рівнями ієрархії, через графічне зображення взаємозв'язку i підпорядкованості стратегічних цілей, оперативних цілей i завдань для наочного їх уявлення (систематизації), вибору показників і критерію оцінювання.

Також Планом дій щодо впровадження оборонної реформи [2] сплановано досягнення визначених стратегічних (оперативних) цілей, розроблення нормативно-правових актів і виконання заходів, які не передбачають розроблення нормативно-правових актів. Декомпозицію оборонної реформи в Україні на ієрархічні рівні, наведено на рис. 1.

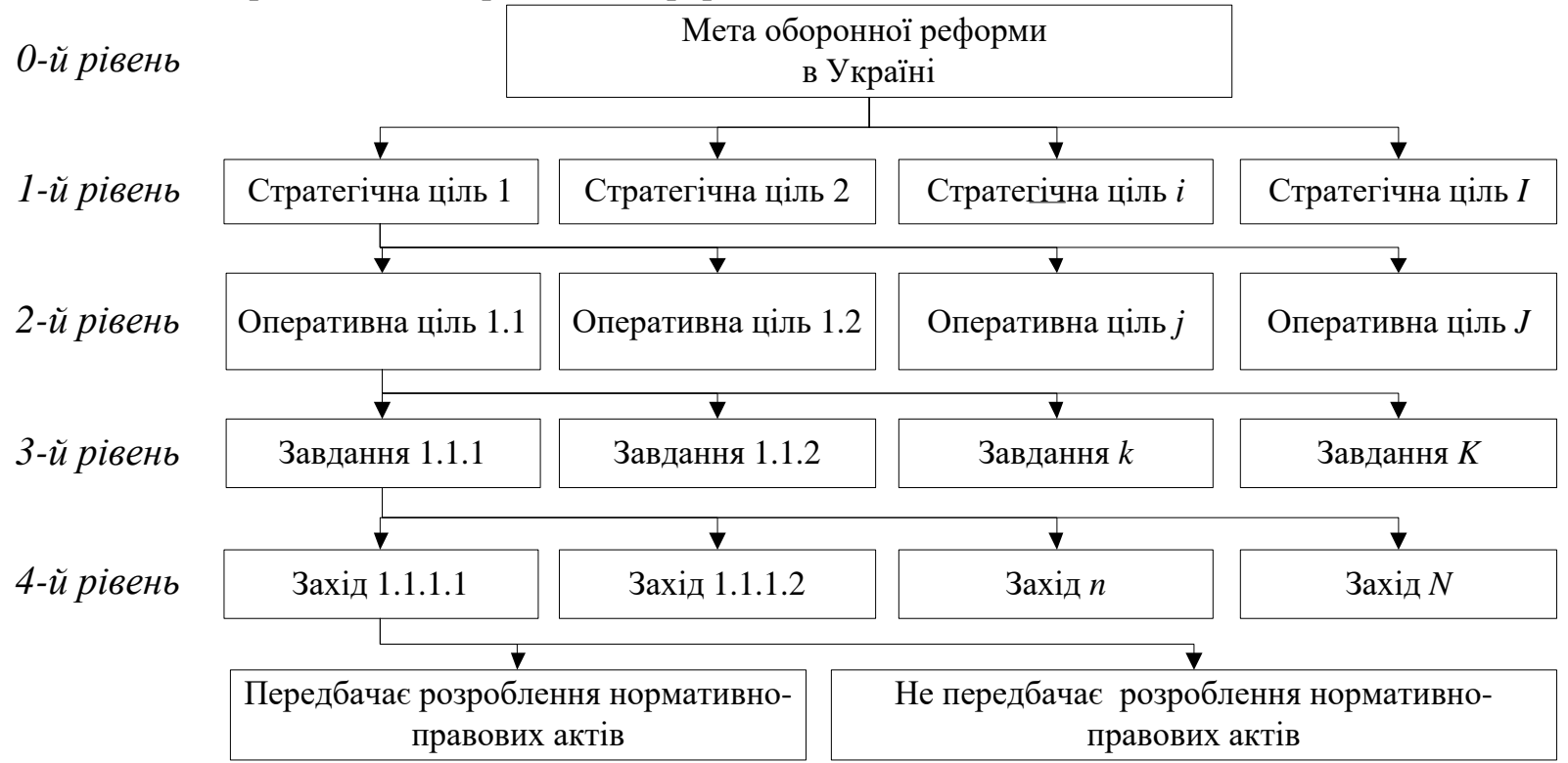

Рис. 1. Іерархічна структура оборонної реформи в Україні

Метою проведення оборонної реформи в Україні є набуття та підтримання силами оборони необхідного рівня бойової готовності та здатності до виконання завдань оборони держави (оборонних спроможностей), ефективного реагування на виникаючі воєнні загрози i воєнно-політичні виклики національній безпеці, підвищення рівня оперативної сумісності 3С України та інших військових формувань з підрозділами збройних сил держав-членів НАТО та СС до виконання спільних завдань у міжнародних операціях із підтримання миру і безпеки [1].

Декомпозиція оборонної реформи в Україні на ієрархічні рівні (див. рис. 1), дає змогу визначити часткові та узагальнений показники оцінювання. Під час оцінювання прийнято вважати, що на кожному рівні сукупність стратегічних (оперативних) цілей або завдань i заходів відповідає очікуваним результатам, строкам виконання (досягнення) вищого рівня та несуперечлива на інших рівнях iєpapxii.
Для визначення вихідних даних обрано Стратегічний оборонний бюлетень України та План дій щодо впровадження оборонної реформи у 2016 - 2020 роках (дорожню карту оборонної реформи) [1-2].

Стратегічні цілі структурно поділено на оперативні цілі, завдання та заходи, тому оцінювання необхідно проводити 3 урахуванням аналізу рівнів ієрархії.

За результатами попередніх досліджень [5], на сьогодні в МО України використовують методику, у якій виконання заходів із розроблення нормативно-правових актів (НПА) визначають лише у відсотках.

Для оцінювання рівня виконання заходів щодо розроблення НПА пропонується користуватися шкалою вимірювання (табл. 1), у якій наведено уточнені коефіцієнти виконання.

Коефіцієнти виконання заходів розраховано через співвідношення нормативного відсотка виконання (100\%) та 
фактичного для приведення до безрозмірного вигляду (від 0 до 1,0).

Таблиця 1

Шкала вимірювання рівня виконання заходів із розроблення нормативно-правового акта

\begin{tabular}{|c|l|c|}
\hline $\begin{array}{c}\text { № } \\
\text { п/п }\end{array}$ & \multicolumn{1}{|c|}{ Зміст заходу } & \multicolumn{1}{|c|}{$\begin{array}{c}\text { Коефіціснт } \\
\text { виконання }\end{array}$} \\
\hline 1 & Розроблено проєкт нормативно-правового акта (нормативного документа) & 0,4 \\
\hline 2 & $\begin{array}{l}\text { Обговорено проєкт з громадськістю, експертами, проведено публічні акції, } \\
\text { опубліковано на сайті Міноборони (у разі потреби) }\end{array}$ & 0,5 \\
\hline 3 & Проведено внутрішнє погодження проєкту, враховано пропозиції та зауваження & 0,6 \\
\hline 4 & $\begin{array}{l}\text { Погоджено проєкт із зацікавленими центральними органами виконавчої влади } \\
\text { (зацікавленими структурними підрозділами) }\end{array}$ & 0,7 \\
\hline 5 & $\begin{array}{l}\text { Отримано висновок Мінюсту (юридичної служби) щодо проєкту і враховано } \\
\text { зауваження }\end{array}$ & 0,8 \\
\hline 6 & $\begin{array}{l}\text { Проєкт подано до КМ України (на підпис керівнику) } \\
\text { Проєкт схвалено на урядовому комітеті, прийнято (зокрема з доопрацюванням) } \\
\text { на засіданні Уряду (підписано наказ) }\end{array}$ & 0,95 \\
\hline 8 & $\begin{array}{l}\text { Випущено постанову (розпорядження) КмУ, подано і зареєстровано у } \\
\text { Верховній Раді України законопроєкт (прийнято рішення Ради національної } \\
\text { безпеки і оборони Україн та введено в дію Указом Президента України) } \\
\text { (доведено до тих, кого стосується) }\end{array}$ & 1,0 \\
\hline
\end{tabular}

Для оцінювання рівня виконання заходів, які не передбачають розроблення НПА, пропонується використовувати розроблену шкалу вимірювання (табл. 2).

Визначати рівень виконання заходів, які не передбачають розроблення НПА, мають відповідні особи, які проводять оцінювання.
Для оцінювання результатів оборонної реформи (див. рис. 1) обрано часткові показники, які характеризують рівень виконання завдань, рівень досягнення оперативних цілей, рівень досягнення стратегічних цілей, узагальнений показник, який характеризує рівень досягнення мети оборонної реформи в Україні.

Таблиця 2

Шкала вимірювання рівня виконання заходів, які не передбачають розроблення нормативно-правових актів

\begin{tabular}{|c|l|c|}
\hline $\begin{array}{c}\text { № } \\
\text { п/п }\end{array}$ & \multicolumn{1}{|c|}{ Рівень виконання заходів } & $\begin{array}{c}\text { Коефіцієнт } \\
\text { виконання }\end{array}$ \\
\hline $\mathbf{1}$ & $\begin{array}{l}\text { Виконано (завершено або завершується виконання згідно з установленими строками та } \\
\text { ресурсами) }\end{array}$ & $>0,9$ \\
\hline $\mathbf{2}$ & Виконано частково (потребує додаткового часу та ресурсів для виконання) & $0,9-0,5$ \\
\hline $\mathbf{3}$ & Не виконано (не почато виконання, не забезпечено ресурсами тощо) & $<0,5$ \\
\hline
\end{tabular}

Часткові показники, які характеризують рівень виконання завдання, пропонується оцінювати за такою залежністю:

$$
Z_{i j k}=\frac{1}{N} \sum_{n=1}^{N} W_{i j k n},
$$

де $Z_{i j k}$ - частковий показник виконання $k$-го завдання $j$-ї оперативної цілі $i$-ї стратегічної цілі;

$W_{i j k n}$ - коефіцієнт виконання $n$-го заходу $k$-го завдання $j$-ї оперативної цілі $i$-ї стратегічної цілі;

$N$ - загальна кількість заходів.

Рівень досягнення оперативної цілі оцінюватимемо за залежністю, аналогічною (2):

$$
B_{i j}=\frac{1}{K} \sum_{k=1}^{K} Z_{i j k}
$$

де $B_{i j}$ - частковий показник досягнення $j$-ї оперативної цілі $i$-ї стратегічної цілі;

$K$ - загальна кількість завдань.

Аналогічно залежностям оцінюватимемо рівень досягнення стратегічної цілі:

$$
C_{i}=\frac{1}{J} \sum_{j=1}^{J} B_{i j}
$$

де $C_{i}-$ частковий показник досягнення $i$-ї стратегічної цілі;

$J$ - загальна кількість оперативних цілей.

Рівень досягнення мети оборонної реформи в Україні можна оцінювати за такою залежністю:

$$
M=\frac{1}{I} \sum_{i=1}^{I} C_{i},
$$


де $M-$ узагальнений показник досягнення мети оборонної реформи;

I - загальна кількість стратегічних цілей.

Структурну схему удосконаленої методики, яка містить етапи оцінювання рівня досягнення стратегічних цілей розвитку спроможностей Збройних Сил за результатами проведеної оборонної реформи, наведено на рис. 2.

Для аналізу отриманих результатів оцінювання i з'ясування рівня досягнення стратегічних цілей і мети оборонної реформи в
Україні, необхідно визначити порогові значення узагальненого показника та область припустимого значення, при якому мета оборонної реформи буде досягнута.

Для такого аналізу застосуємо критерій результативності $\left(K_{O P}\right)$, який визначає ризик досягнення стратегічних цілей $\left(C_{i}\right)$ і мети оборонної реформи $(M)$ при прийнятих значеннях коефіцієнтів, які наведено у табл. 3.

Значення критерію результативності

Таблиця 3

\begin{tabular}{|l|c|}
\hline \multicolumn{1}{|c|}{ Значення критерію $K_{O P}$} & $\begin{array}{c}\text { Коефіціснт досягнення стратегічних цілей і мети } \\
\text { оборонної реформи }\end{array}$ \\
\hline Низький ризик $(\boldsymbol{G})$ & $C_{i} \geq 0,9 ; M \geq 0,9$ \\
\hline Середній ризик $(\boldsymbol{Y})$ & $0,85 \leq C_{i}<0,9 ; 0,85 \leq M<0,9$ \\
\hline Високий ризик $(\boldsymbol{R})$ & $C_{i}<0,85 ; M<0,85$ \\
\hline
\end{tabular}

Низький ризик $(\boldsymbol{G})$ характеризує стан, коли для досягнення стратегічних цілей і мети оборонної реформи немає перешкод. Кількість завдань і заходів, які залишилося виконати, незначна, витрати для їх виконання (часові, ресурсні) не $є$ істотними (рядки таблиць 3 отриманими результатами рекомендовано виділяти зеленим кольором для презентації.

Середній ризик (Y) показує, що рівень виконання завдань i заходів частково задовольняє досягнення стратегічних (оперативних) цілей, тому докладання зусиль i витрата ресурсів у перспективі можуть бути не дуже значними (рядки таблиць рекомендовано виділяти жовтим кольором).

Високий ризик $(\boldsymbol{R})$ означає, що рівень досягнення визначених стратегічних (оперативних) цілей $\epsilon$ незначним, передбачає виконання завдань i заходів із залученням великих фінансових та інших ресурсів або потребує перегляду (рядки таблиць рекомендовано виділяти червоним кольором);

Значення критерію результативності дають змогу проаналізувати стан виконання завдань і заходів оборонної реформи, рівень досягнення стратегічних та оперативних цілей $i$ ризику. Зокрема за наявності високого ризику необхідно переглянути визначені заходи i завдання, оперативні та стратегічні цілі, прогнозовані ймовірні сценарії застосування Збройних Сил, необхідні амбіційні спроможності, а також можливість додаткового фінансування (із бюджету, допомоги інших держав та благодійних організацій) на прогнозований період.
Значення показника досягнення $i$-ї

стратегічної цілі $\left(C_{i}\right)$ та узагальненого показника досягнення мети оборонної реформи ( $M$ ) має бути $\geq 0,9$ (90\%), до того ж буде “незначний ризик” досягнення стратегічних цілей і мети оборонної реформи. Повним досягненням стратегічної цілі розвитку ЗС України за результатами проведеної оборонної реформи вважатимемо $C_{i}=1,0$ (100\% досягнення стратегічної цілі).

$$
\text { Отже, обраний критерій }
$$

результативності, який характеризує рівень досягнення стратегічних цілей $\mathrm{i}$ мети оборонної реформи, має конкретний фізичний зміст, виражає результативність проведення оборонної реформи та враховує ризик їх досягнення, a удосконалена методика дає змогу оцінити результативність оборонної реформи 3 урахуванням визначених етапів (за роками) i ступінь ризику.

Для оцінювання рівня досягнення стратегічних цілей із розвитку Збройних Сил за результатами проведеної оборонної реформи, а також аналізу річних (щоквартальних) результатів досягнення стратегічних цілей, пропонується скористатися табл. 4 та залежностями (2)(5).

Якщо $C_{i}<0,9$ та $M<0,9$ наступним етапом щодо закінчення оцінювання, буде розроблення рекомендацій щодо підвищення рівня досягнення стратегічних цілей та мети оборонної реформи. 


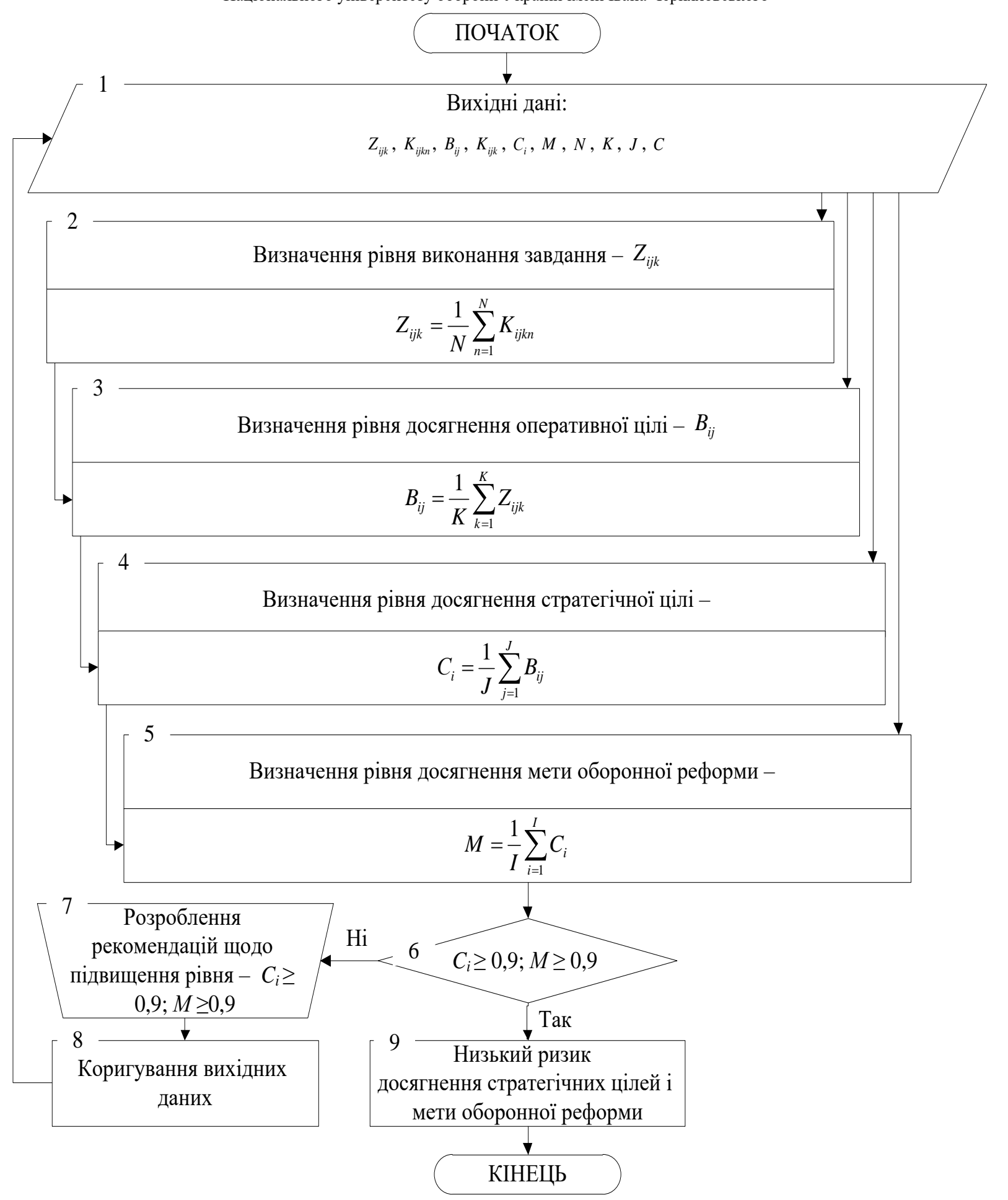

Рис. 2. Структурна схема оцінювання рівня досягнення стратегічних цілей розвитку Збройних Сил за результатами проведеної оборонної реформи

Отже, отримані результати дають змогу проаналізувати рівень досягнення мети оборонної реформи, стратегічних та оперативних цілей, виконання завдань і заходів станом на визначений період, а також розробити рекомендації (визначити пріоритети) на наступний рік для мінімізації ризиків.

Удосконалену методику можуть застосовувати члени Міжвідомчої робочої групи з питань проведення оборонного огляду, щоб забезпечувати керівництво МО України та ГШ ЗС України оперативною та об'єктивною інформацією про рівень виконання заходів і завдань оборонної реформи, рівень досягнення оперативних i стратегічних цілей із розвитку Збройних Сил, а також інші органи військового управління. 
Рівень досягнення стратегічних цілей розвитку Збройних Сил за результатами проведеної оборонної реформи (приклад)

\begin{tabular}{|c|c|c|c|}
\hline Показники оцінювання & Термін виконання & $\begin{array}{l}\text { Рівень досягнення } \\
\text { станом на } 12.2019\end{array}$ & Ризик досягнення \\
\hline Мета оборонної реформи & 12.2020 & $0,798(79,8 \%)$ & $\bar{R}$ \\
\hline Стратегічна ціль 1 & 12.2020 & $0,875(87,5 \%)$ & $Y$ \\
\hline Оперативна ціль 1.1 & 12.2020 & $0,744(74,4 \%)$ & $\bar{R}$ \\
\hline Завдання 1.1.1 & 12.2018 & $0,867(86,7 \%)$ & $\boldsymbol{Y}$ \\
\hline Захід 1.1.1.1 & 12.2017 & $1,0(\mathbf{1 0 0} \%)$ & $G$ \\
\hline Захід 1.1.1.2 & 06.2018 & $0,9(\mathbf{9 0} \%)$ & $G$ \\
\hline Захід 1.1.1.3 & 12.2018 & $0,7(70 \%)$ & $\boldsymbol{R}$ \\
\hline Завдання 1.1.2 & 12.2019 & $0,767(76,7 \%)$ & $\bar{R}$ \\
\hline Захід 1.1.2.1 & 12.2018 & $1,0(100 \%)$ & $G$ \\
\hline Захід 1.1.2.2 & 06.2019 & $0,8(80 \%)$ & $\boldsymbol{R}$ \\
\hline Захід 1.1.2.3 & 12.2019 & $0,5(50 \%)$ & $\boldsymbol{R}$ \\
\hline Завдання 1.1.k & 12.2020 & $0,6(60 \%)$ & $R$ \\
\hline Захід 1.1.1.n & 09.2019 & $1,0(100 \%)$ & $G$ \\
\hline Захід 1.1.1.n & 12.2020 & $0,7(70 \%)$ & $R$ \\
\hline Захід 1.1.1.n & 12.2020 & $0,1(10 \%)$ & $R$ \\
\hline \multicolumn{4}{|l|}{ Оперативна ціль ... } \\
\hline Завдання ... & $\ldots$ & .. & $\ldots$ \\
\hline Захід ... & & & \\
\hline
\end{tabular}

Висновки. Запропонована удосконалена методика 3 використанням запропонованих шкал вимірювання та критерію результативності дає змогу об'єктивніше оцінювати результати оборонної реформи та ризики 3 будь-яким ступенем деталізації завдань і заходів, на будь-якому етапі іiі проведення для прийняття обгрунтованих рішень i розроблення відповідних рекомендацій.

Перспектива подальших досліджень. Подальші дослідження доцільно присвятити удосконаленню методів стратегічного планування розвитку Збройних Сил України на основі спроможностей.

\section{СПИСОК ВИКОРИСТАНОЇ ЛІТЕРАТУРИ}

1. Указ Президента України "Про рішення Ради національної безпеки i оборони України від 20.05.2016 "Про Стратегічний оборонний бюлетень України” від 06.06.2016 № 240/2016 // Урядовий кур'єр від 15.06.2016 № 112.

2. План дій щодо впровадження оборонної реформи у 2016-2020 роках (дорожня карта оборонної реформи) : затв. Міністром оборони України $15.08 .2016 . \quad$ URL: http://www.mil.gov.ua/content/ tenders/ Plan_2208.pdf.

3. Положення про Міжвідомчу робочу групу 3 питань проведення оборонного огляду : затв. наказом Міністерства оборони України від 18.03.2019 № 114. URL: https://zakon.rada.gov.ua/ laws/show/ z040119/print.

4. Методичні рекомендації 3 організації та проведення оборонного огляду: затв. Міністром оборони України 07.06.2019. 84 с.
5. Устименко О. В.,

Павліковський А. К., Фучко А. Й., Фесянов П. О. Методика оцінки досягнення стратегічних (оперативних) цілей Плану дій щодо впровадження оборонної реформи у 2016-2020 роках. Збірник наукових прачь ЦВСД НУОУ імені Івана Черняховського. Київ, 2016. № 3 (58). С. 115-121.

6. Скиба П. П. "Будівництво і розвиток" Збройних Сил України, або як пройти шлях від воєнної організації держави до з'єднання. Славута, 2013. $269 \mathrm{c}$.

7. Створення наукових засад будівництва Збройних Сил України - головне завдання національної воєнної науки. Наука і оборона. Київ, 2012. № 1. C. 3-6.

8. Методичні рекомендації щодо складання стратегічних планів підприємствами державного сектору. URL: http://www.me.gov.ua/ Documents/Detail?lang=uk-UA\&id=e00a80483758-4996-9c9a-dfdcfbe8a684 \&title=Dokumenti.

9. Саганюк Ф. В., Фролов В. С. Системний підхід до реалізації оборонної реформи в Україні. Збірник наукових прачь ЦВСД НУОУ імені Івана Черняховського. Київ, 2018. № 1 (62). С. 13-18.

10. Сурков О. О. Удосконалена методика оцінювання часткових показників системи комплектування офіцерами запасу Сухопутних військ. Збірник наукових праџь ЦВСД НУОУ імені Івана Черняховського. Київ, 2012. № 2 (46). C. 100-105.

11. Сурков О. О. Методичний підхід до формалізації стратегічного планування розвитку спроможностей Збройних Сил та інших складових сил оборони. Збірник наукових прачь ЦВСД НУОУ імені Івана Черняховського. Київ, 2018. № 1 (62). C. 34-40.

12. Сурков О. О. Концептуальний підхід до вибору пріоритетних напрямів розвитку спроможностей Збройних Сил України та інших складових сил 
оборони. Збірник наукових працьь ЦВСД НУОУ імені Івана Черняховського. Київ, 2018. № 2 (63). C. 39-45.

13. Сурков О. О. Аналіз сутності і логіка формування методології стратегічного планування розвитку Збройних Сил України на основі національної безпеки: історія, сучасність, перспективи : матеріали III підсумкової наук.практ. конф. Київ : УДО України, 2019. С. 179181.

14. Орловский П. Н. Системный анализ : учеб. пособ. [для студ. экон. спец.]. Киев : Ин-т содержания и методов обучения, 1996. 360 с.

Стаття надійшла до редакційної колегії 24.10.2019

Сурков О. А., канд. воен. наук

Центр военно-стратегических исследований Национального университета обороны Украины имени Ивана Черняховского, Киев

Усовершенствованная методика оценки уровня достижения стратегических целей развития Вооруженных Сил по результатам проведенной обороной реформы

Резюме. В статье предложено использование усовершенствованной методики оценки уровеня достижения стратегических целей развития Вооруженных Сил по результатам проведенной оборонной реформы в ходе проведенного обзора.

Ключевые слова: методика; развитие Вооруженных Сил; результаты оборонной реформы; стратегические цели; оборонительный обзор.

\section{O. Surkov, PhD (Military)}

Center for Military and Strategic Studies of the National Defence University of Ukraine named after Ivan Cherniakhovskyi, Kyiv

Improved methodology for assessing the level of achievement of the Armed Forces development based on the results of defense reforms

Resume. The article proposes the use of advanced methods of assessing the level of achievement of the strategic goals of the Armed Forces development on the results of defense reforms carried out during the defense review.

Keywords: method; the development of the Armed Forces; the results of defense reform; strategic goals; defense review. 